\title{
Epigenomics in cancer management
}

\author{
This article was published in the following Dove Press journal: \\ Cancer Management and Research \\ 27 October 2010 \\ Number of times this article has been viewed
}

\section{Fabricio F Costa \\ Cancer Biology and Epigenomics Program, Children's Memorial Research Center and Northwestern University's Feinberg School of Medicine, 2430 N. Halsted St, Box 220, Chicago, IL, USA}

Correspondence: Fabricio F Costa Cancer Biology and Epigenomics Program, Children's Memorial Research Center and Northwestern University's Feinberg School of Medicine, 2430 N. Halsted St, Box 220, Chicago, IL, USA

Tel +I 7738804000 ext. 57312

Fax + I 773755655 I

Email fcosta@childrensmemorial.org

\begin{abstract}
The identification of all epigenetic modifications implicated in gene expression is the next step for a better understanding of human biology in both normal and pathological states. This field is referred to as epigenomics, and it is defined as epigenetic changes (ie, DNA methylation, histone modifications and regulation by noncoding RNAs such as microRNAs) on a genomic scale rather than a single gene. Epigenetics modulate the structure of the chromatin, thereby affecting the transcription of genes in the genome. Different studies have already identified changes in epigenetic modifications in a few genes in specific pathways in cancers. Based on these epigenetic changes, drugs against different types of tumors were developed, which mainly target epimutations in the genome. Examples include DNA methylation inhibitors, histone modification inhibitors, and small molecules that target chromatin-remodeling proteins. However, these drugs are not specific, and side effects are a major problem; therefore, new DNA sequencing technologies combined with epigenomic tools have the potential to identify novel biomarkers and better molecular targets to treat cancers. The purpose of this review is to discuss current and emerging epigenomic tools and to address how these new technologies may impact the future of cancer management.
\end{abstract}

Keywords: genomics, epigenomics, epigenetics, DNA methylation, histone modifications, new technologies, cancer management

\section{Introduction}

Sequencing the human genome marked not the end of the field of genomics, but its beginning. Scientists now stand in a unique position in the history of medicine to define human disease, armed with the technological advancements and the data that has resulted from the Human Genome Project. ${ }^{1,2}$ Using this information, some progress has already been made toward launching individualized and personalized medicine, especially for certain types of cancer. For example, the launch of different types of genetic tests to predict disease (preventive medicine) and the development of the drug imatinib (Gleevec $^{\circledR}$ ) for blood tumors ${ }^{3}$ were major breakthroughs. In addition, biomarkers that are able to subgroup tumors based on aggressivity, thus aiding in clinical decisions, were also identified. ${ }^{4}$ A precise molecular characterization of human cancers will allow a better understanding of the basis for disease susceptibility and environmental influence, better diagnosis and prognosis, and the refinement of individualized treatment for optimal therapeutic efficacy.

Genomes from various individuals have already been sequenced, ${ }^{5,6}$ allowing genomic comparisons. Projects such as the $\operatorname{HapMap}^{7}$ that identified variations in the human genome, and $\mathrm{ENCODE}^{8}$ that is analyzing the functional elements in the genome, are helping in the understanding of complex disease phenotypes. Such projects have the 
potential to help elucidate the information encoded by human genomes and aid in the treatment of diseases such as cancer.

One of the main issues in genomic science is understanding how gene expression is regulated. To understand the mechanisms that are implicated in gene regulation, the genes that are expressed in each cell type of the body and how changes in their expression will impact in the development of diseases represent major challenges. In addition, environmental factors such as the exposure to chemical compounds during life, smoking, and nutrition can clearly affect and change the expression of genes. ${ }^{9}$ Thus, in the post-genomic era, studies of how human genes are regulated and the mechanisms that are implicated in this process are of major importance for our understanding of normal processes and diseased states.

The information beyond the genome sequence was recently coined as the epigenome. ${ }^{10}$ The epigenome is defined as the group of modifications that can occur at a genomic level that will not change the sequence of the bases of the DNA but can change the DNA conformation and, as a consequence, change the expression of genes. Epigenetics is the study of these modifications in the DNA. ${ }^{11}$ The following are the main epigenetic modifications that occur in the DNA molecule: 1) binding of different proteins to the DNA such as histones and methyl-binding proteins, 2) addition of chemical groups in the bases of the DNA such as methyl (CH3), and 3) microRNAs and other noncoding RNAs that can regulate the expression of genes through various mechanisms.

While epigenetics has garnered more attention, it is not a new field, and studies dating from the 1980s have shown the promise of using drugs that affect these mechanisms to treat diseases, especially cancers. ${ }^{12,13}$ In the last decade, we have been facing an overwhelming increase in drugs affecting epigenetic mechanisms that have been developed to treat different types of cancer (see Table 1 and Figure 1). Examples are a growing number of DNA methylation inhibitors, histone modification inhibitors, and small molecules that target chromatin-remodeling proteins. 5-Azacytidine was the first inhibitor of an enzyme implicated in epigenetic modifications described. ${ }^{14}$ This drug inhibits the DNA methyltransferase (DNMT) enzyme that is responsible for adding methyl groups to cytosines located in both DNA and RNA molecules. Another example of a DNMT inhibitor is

Table I Drugs developed using epigenetics and epigenomics tools

\begin{tabular}{|c|c|c|c|}
\hline Drug & Mode of action & Types of cancer & References \\
\hline Belinostat $^{\prime}$ & Histone deacetylase inhibitor & $\begin{array}{l}\text { Hematological malignancies and } \\
\text { solid tumors }\end{array}$ & 71,72 \\
\hline $\begin{array}{l}\text { Dacogen }^{\circledast 1} \text { or Vidaza } \\
\text { and decitabine }\end{array}$ & $\begin{array}{l}\text { DNA methyltransferase inhibitors } \\
\text { (5-azacytidine and 5-aza-2'-deoxycytidine) }\end{array}$ & $\begin{array}{l}\text { Myelodysplastic syndrome and } \\
\text { hematological malignancies. Tests } \\
\text { have already started in solid tumors }\end{array}$ & $38,73,74$ \\
\hline DZNep' (Deazaneplanocin A) & Histone methyltransferase inhibitor & Acute myeloid leukemia & 75 \\
\hline Entinostat' (MS-275) & Benzamide histone acetylase inhibitor & Blood and lung tumors & 72,76 \\
\hline Panobinostat' (LBH589) & $\begin{array}{l}\text { Inhibitor of the enzyme histone deacetylase } \\
\text { in a mechanism leading to apoptosis } \\
\text { of malignant cells via multiple pathways }\end{array}$ & $\begin{array}{l}\text { Cutaneous T-cell lymphoma, chronic } \\
\text { myelogenous leukemia, myelodysplastic } \\
\text { syndromes, breast cancer, pancreatic } \\
\text { cancer, and prostate cancer }\end{array}$ & $77-79$ \\
\hline RGI08 & $\begin{array}{l}\text { Small molecule specifically designed to bind } \\
\text { and inhibit the active domain of the DNA } \\
\text { methyltransferase I enzyme }\end{array}$ & Different types of cancer & 80 \\
\hline CP- $4200^{3}$ & $\begin{array}{l}\text { Molecule conjugated to a lipid chain linked } \\
\text { to azacytidine that accelerates cellular uptake }\end{array}$ & Different types of cancer & 81 \\
\hline $\mathrm{SII} 0^{3}$ & $\begin{array}{l}\text { Modified and less toxic version of } 5 \text {-aza-2'- } \\
\text { deoxycytidine; DNA methyltransferase inhibitor }\end{array}$ & Different types of cancer & 82 \\
\hline Romidepsin' & $\begin{array}{l}\text { Natural product that inhibits histone } \\
\text { deacetylases and causes } \\
\text { cancer cell apoptosis }\end{array}$ & $\begin{array}{l}\text { Under clinical trials to cutaneous T-cell } \\
\text { lymphoma, peripheral T-cell lymphoma, } \\
\text { and a variety of other cancers }\end{array}$ & 83 \\
\hline Valproic Acid ${ }^{2}$ (Depakote ${ }^{\circledR}$ ) & Histone deacetylase inhibitor & Multiple myeloma, gliomas, and melanoma & 84 \\
\hline Vorinostat $^{2}\left(\right.$ Solinza $\left.^{\oplus}\right)$ & Histone deacetylase inhibitor & $\begin{array}{l}\text { Lymphomas, glioblastoma } \\
\text { multiforme, and other solid tumors }\end{array}$ & 72,85 \\
\hline Pyroxamide $^{2}$ (SAHA) & Histone deacetylase inhibitor & $\begin{array}{l}\text { Hematological malignancies, prostate } \\
\text { cancer, bladder cancer, and neuroblastoma }\end{array}$ & 86 \\
\hline Sirtinol and Salermide ${ }^{3}$ & SIRTI protein inhibitors & Different types of cancer & 43,87 \\
\hline
\end{tabular}

Notes: There might be other examples of epigenetic-based drugs under development and/or in clinical trials that were not described here. 'In clinical trials; ${ }^{2} \mathrm{Approved}$ by the FDA; ${ }^{3}$ Under development. 


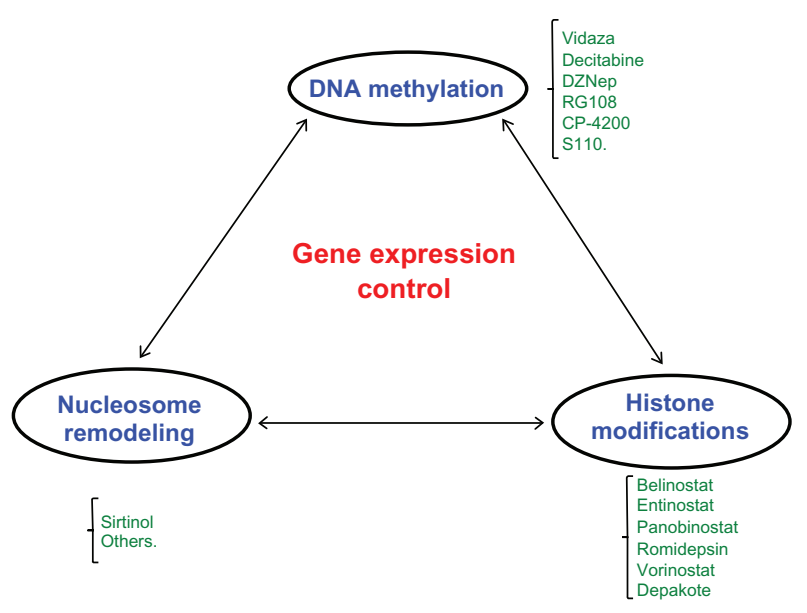

Figure I Epigenomics and cancer therapy. Schematic representation of the three main epigenomic/epigenetic components that are implicated in gene expression control in human cells (blue). Some drugs that are in current use, under development, and in clinical trials for each epigenetic mechanism of gene regulation are shown in green. The drugs presented here are just a representative list for each mechanism, and some drugs under development and in clinical trials at the moment are not shown.

5-aza-2'-deoxycytidine, which is incorporated just in the DNA molecule. The DNA methyltransferase covalently binds to these nucleotide analogs, and this sequestration affects its normal function. These compounds can also affect the way proteins implicated in cell regulation are able to bind to the DNA/RNA substrates. 5-Azacytidine was first tested in myelodysplastic syndrome and leukemia, and it showed promising results in patients with both diseases. ${ }^{15,16}$ Since 5 -azacytydine and other epigenetic drugs are not very specific, side effects are a major problem. A challenge faced by researchers in this field is two-fold: design more specific drugs and drugs that have fewer side effects since they have a global effect in the epigenome of the cells. To overcome this issue, new DNA sequencing technologies (second and third generation) combined with epigenomic tools have emerged. It is becoming clear that these technologies may facilitate the identification of better molecular targets for drug development and biomarker identification for cancer management. In that regard, the main purpose of this review is to discuss the emergence of epigenomic tools derived from new DNA sequencing technologies and how they may affect the management of cancer in the future.

\section{Cancer genomics - now and then}

Genomics is defined as the study of entire genomes of organisms, including extrachromosomal DNA such as the mitochondrial genetic material. This field includes intensive efforts to determine the entire DNA sequence of organisms, using fine-scale genetic mapping and DNA sequencing with current and emerging technologies. In contrast, investigating the roles of single genes is a primary focus of genetics. Single gene research does not fall into the definition of genomics unless the aim is to verify the effect that a gene may have on the entire genome's networks and pathways. Genomics has been the main focus in molecular biology, especially after the completion of the sequencing of genomes from several organisms. Genomics tools have already helped in the understanding of several aspects of the genome of cancer cells when compared to normal controls. One important example is the identification of the gene HER2/neu (ErbB-2), which is an oncogene mapped to human chromosome 17 that is overexpressed, or amplified, in $\sim 30 \%$ of breast cancer tumors. ${ }^{17}$ Identification of this molecular characteristic culminated in the development of the drug trastuzumab $\left(\right.$ Herceptin $\left.^{\circledR}\right){ }^{18}$ Breast cancer patients that are HER2/neu (ErbB-2) positive have increased survival rates when treated with this drug. ${ }^{18}$

One question that has recently emerged after the sequencing of entire human genomes and comparisons between them is 'What have we learned from sequencing human genomes?' It is clear that important advances were generated after the sequencing of the first human genome a decade ago. These advancements were mainly applied to basic science such as improvements in DNA sequencing technologies, a decrease in the cost for sequencing the DNA molecule, and also the development of new methods to analyze molecular changes in diseases; for example, there was an increase in the number of predictive and prognostic genetic tests for cancers and other diseases. In contrast, for applied medicine and patients, there have been a disappointingly small number of drugs and therapies that were discovered and developed using genomics tools. Hence, we have learned that the sequence of human genomes is just a starting point to generate and accumulate the basic information needed for more complex and deeper analyses.

Recently, cancer genomes were sequenced and compared with normal cells for leukemia, breast, lung, and other tumor types, using second-generation DNA sequencing technologies. ${ }^{19-25}$ The purpose was to identify mutations that could give rise to new biomarkers and new therapies for these types of cancers. In addition, the 1000 Genome Project was recently launched ${ }^{26}$ with the objective of sequencing the genome of thousands of individuals in a small period of time. In parallel, companies are starting to provide whole genome sequencing services, with the aim of understanding the individual's susceptibility for diseases, including different cancers. ${ }^{27}$ As a result, a large number of individuals will have their genomes sequenced in the years to come. But is this enough to understand how the human cell machinery works 
and to determine how cancer or any other disease arises? It is likely that the technology will be beneficial to genomic science in the future by paving new ways of approaching diseases, especially cancers. Even though the genomic information will be of importance to identify mutations and other chromosomal abnormalities (ie, insertions or deletions in the genomic DNA of diseased cells), more studies will be necessary to completely understand human genomes. In this regard, the big challenge will be to identify and catalog all the genes that are present in normal cells and their defects (mutations, deletions, insertions, amplifications, fusion proteins, etc) in tumors. There is growing evidence that epigenomics will contribute to this understanding, and in the following sections, I will discuss drugs based on epigenetic mechanisms that are currently in use, in clinical trials, and under development. Furthermore, I will also discuss how this field could aid in the development of better therapies for cancer and in the identification of new biomarkers.

\section{Epigenomics and new therapies}

Epigenomics is becoming more important as the technologies for genome-wide epigenetic modification analyses improve. The best-known epigenetic marker is DNA methylation, and some genes are already described with this epigenetic change in different tumor types. ${ }^{28}$ DNA methylation occurs in normal cells mainly in regions that are intergenic, and loss of methylation (hypomethylation) in these areas was first reported in the 1980s. ${ }^{29}$ Loss of DNA methylation or global hypomethylation is an early event in cancer, and when it occurs in repetitive regions of the genome, the consequences can be chromosomal instability, as previously described. ${ }^{30}$ On the other hand, gain of DNA methylation (hypermethylation) in the promoter region of different genes can lead to a decrease in the expression of this gene (also known as downregulation) and can be one of the causes for cancer development. ${ }^{31}$ It is hypothesized that DNA methylation may affect gene expression by blocking transcription after methyl-binding and other proteins form a complex that blocks the access for transcription factors to the gene promoter. ${ }^{32}$ However, there are other models suggesting that DNA methylation is the consequence instead of the cause of gene inactivation. ${ }^{33}$ In this case, defects in the transcription factors such as mutations will leave promoter regions 'opened' and more susceptible to the action of the DNMTs. ${ }^{33}$ Consequently, these regions of the DNA will be methylated. ${ }^{33}$

Different genes are already described as hypermethylated in the initiation and progression of several types of tumors. ${ }^{34}$ The enzymes responsible for the control of DNA methylation in eukaryotic cells are the DNMTs. ${ }^{35}$ There are three enzymes already described: DNMTs 1, 2, and 3. However, DNMT1 may be the most important, especially in diseases such as cancer. ${ }^{36}$ Different types of drugs that target DNMTs have already been developed. The idea behind using a drug that blocks the enzymes that control DNA methylation is that in cancer, there is an increase in their activity. ${ }^{37}$ Drugs that block DNMTs include 5-azacytidine, 5-aza-2'-deoxycytidine, small molecule inhibitors, and others (see Table 1 for more details). 5-Azacytidine (Vidaza ${ }^{\circledR}$ ) was approved by the Food and Drug Administration (FDA) since it increased the survival of patients with myelodysplastic syndrome, and many patients on Vidaza became transfusion independent, showing the potential for this type of therapy. ${ }^{38}$

Histone marks were recently described as an important epigenetic modification to control gene expression in normal cells. ${ }^{39}$ Histone modifications, such as methylation, acetylation, ADP-ribosylation, ubiquitination, phosphorylation, and others, to histone tails alter chromatin structure. However, a complete understanding of the precise molecular mechanisms by which these alterations to histone tails influence DNA-histone interactions remains elusive. There are two main hypothesis on how histone modifications can affect chromosome function: 1) they may alter the electrostatic charge of the histone, resulting in a structural change in histones or their binding to DNA; or 2 ) these modifications are binding sites for protein recognition motifs, such as the bromodomains or chromodomains, that recognize acetylated lysines or methylated lysines, respectively. ${ }^{40}$ The existence of these modifications and recognition motifs led to the 'histone code' hypothesis proposed by Strahl and Allis. ${ }^{41}$ Overall, post-translational modifications of histones create an epigenetic mechanism for the regulation of a variety of normal and disease-related processes, including cancers. Drugs affecting histone modifications have been already developed and showed promising results in the treatment for different tumor types (see Table 1 for more details).

Based on this knowledge, different types of histone deacetylase inhibitors, DNMT inhibitors, and small molecules that block enzymes that are implicated in these epigenetic mechanisms have been developed. In addition, combining conventional therapies to drugs that affect epigenetic mechanisms is becoming common. For example, clinical trials using a combination of DNMT inhibitors with conventional chemotherapy were well tolerated in cancer patients and showed encouraging results when compared with chemotherapy alone. ${ }^{42}$

Drugs targeting chromatin and nucleosome remodeling proteins are also a promising therapeutic strategy to treat human cancers (Table 1). Some of these proteins 
are deregulated in cancer, such as sirtuin 1 (SIRT1). It was recently shown that targeting this protein with drugs such as Salermide or Sirtinol can lead to the reactivation of pro-apoptotic genes that are epigenetically repressed exclusively in cancer cells. ${ }^{43}$ These drugs are also promising as an anticancer agent, providing molecular evidences that SIRT1 might be involved in human tumorigenesis. ${ }^{43}$ Chromatin-remodeling proteins are important for proper gene expression, and new drugs targeting these proteins will be developed generating more effective therapies against cancer. All the epigenetic/epigenomic mechanisms and some of the drugs that have been tested for cancer therapies are represented in Figure 1.

\section{The impact of new technologies on cancer research}

Second-generation DNA sequencing technologies have been used to identify and detect genetic and genomic changes in tumors when compared with normal cells. In the epigenomics field, these technologies have been helpful in identifying regions of the DNA that are differentially methylated and have different histone marks. ${ }^{44}$ The identification of proteins that are responsible for wrapping the nucleosome of tumor cells was also possible ${ }^{44}$ (see Table 2). The development of new technologies to study cancer epigenomes will be crucial for the identification of defects in tumor cells.

Thirty years ago, sodium bisulfite was first described as a reagent that could be used to detect DNA methylation in specific regions of the DNA. ${ }^{45}$ This discovery has revolutionized the way we have been analyzing DNA methylation changes in cancer cells from different tumor types. ${ }^{45}$ This technology allowed the analyses of specific regions of the DNA, the so-called gene-by-gene analyses (Table 2), to evaluate the percentages of DNA methylation and correlate it to gene expression. In addition to sodium bisulfite treatment, digestion with methylation-sensitive restriction enzymes and several different methods using restriction enzymes combined with polymerase chain reaction ${ }^{46}$ have been used for years. Some limitations of these methods include the low number of dinucleotide CGs or CpGs that can be analyzed at a time (Table 2). Analyses of individual genes and/or regions of the DNA may also be applied to evaluate histone marks and nucleosome packaging, with the use of antibodies against specific marks in the histone proteins. These procedures, however,

Table 2 Different types of technologies to uncover epigenomic changes in cancer

\begin{tabular}{|c|c|c|c|}
\hline Method(s) & Description & Examples & References \\
\hline $\begin{array}{l}\text { Gene-by-gene } \\
\text { analyses }\end{array}$ & $\begin{array}{l}\text { Different methods that are used to evaluate methylation status of } \\
\text { gene promoters. The most utilized technology is based in } \\
\text { sodium bisulfite treatment that converts unmethylated citosines to } \\
\text { uracil by deamination. Methylation changes are easily detected using } \\
\text { this method after DNA sequencing. Other methods include digestion } \\
\text { with MSRE and antibodies against methyl-binding proteins that } \\
\text { can be used to detect specific methylation changes. }\end{array}$ & $\begin{array}{l}\text { MSRE digestion, bisulfite } \\
\text { sequencing, MSP, MethyLight, } \\
\text { and others }\end{array}$ & $45,46,88,89$ \\
\hline ChiP-ChiP arrays & $\begin{array}{l}\text { Specific antibodies are used for proteins (ie, histones) that are } \\
\text { binding to the DNA followed by array hybridization. Mainly used } \\
\text { to identify regions that are active and/or inactive based on } \\
\text { epigenetic modifications. }\end{array}$ & $\begin{array}{l}\text { Chromatin immunoprecipitation } \\
\text { combined with microarray } \\
\text { hybridization }\end{array}$ & 90 \\
\hline $\begin{array}{l}\text { ChiP-Seq } \\
\text { technology }\end{array}$ & $\begin{array}{l}\text { Specific antibodies are used for proteins (ie, histones) that are binding } \\
\text { to the DNA followed by DNA sequencing to map the locations of the } \\
\text { histone proteins in the genome and their specific modifications. Second- } \\
\text { generation DNA sequencing has been used to uncover these changes. }\end{array}$ & $\begin{array}{l}\text { Chromatin immunoprecipitation } \\
\text { combined with DNA sequencing }\end{array}$ & 91 \\
\hline $\begin{array}{l}\text { DNA } \\
\text { methylation arrays }\end{array}$ & $\begin{array}{l}\text { Different types of DNA methylation arrays have been used such } \\
\text { as arrays containing CG-rich regions of the DNA. Whole genome } \\
\text { arrays are also generated after bisulfite conversion of the DNA. }\end{array}$ & $\begin{array}{l}\text { CpG island specific arrays, } \\
\text { whole genome bisulfite arrays }\end{array}$ & 92,93 \\
\hline $\begin{array}{l}\text { Second-generation } \\
\text { DNA sequencing }\end{array}$ & $\begin{array}{l}\text { Methodologies based on pyrosequencing and other technologies } \\
\text { are allowing the generation of huge amounts of genomic and } \\
\text { trascriptomic data. They have been also used to detect } \\
\text { epigenomic modifications in human genomes. }\end{array}$ & $\begin{array}{l}\text { Pyrosequencing, sequencing } \\
\text { by oligo ligation and } \\
\text { detection, sequencing } \\
\text { by synthesis, and others }\end{array}$ & 94,95 \\
\hline $\begin{array}{l}\text { Third-generation } \\
\text { DNA sequencing }\end{array}$ & $\begin{array}{l}\text { This new generation comprises methodologies that will be available soon } \\
\text { mainly based in nanotechnology (ie, nanopores and nanodetectors). } \\
\text { These new methods have the potential to decrease the costs of } \\
\text { sequencing a genome in a faster way than the current technologies. } \\
\text { Applications for epigenomic analyses have been recently reported. }\end{array}$ & $\begin{array}{l}\text { SMRT, nanosequencing, } \\
\text { and others }\end{array}$ & $47,48,96-99$ \\
\hline
\end{tabular}

Abbreviations: ChiP, chromatin immunoprecipitation; MSP, methylation-specific PCR; MSRE, methylation-sensitive restriction enzymes; SMRT, single molecule real time PCR. 
are very laborious and restricted to the region(s) of interest. Recent methods were developed for epigenomic analyses, which can evaluate epigenetic changes on a global level in the genome of tumor cells (Table 2). Examples include chromatin immunoprecipitation combined with DNA sequencing (ChiP-Seq) and high-throughput DNA methylation analyses after sodium bisulfite treatment using new DNA sequencing technologies (Table 2). Second-generation DNA sequencing methods are mainly based on pyrosequencing and emulsion polymerase chain reaction combined with beads that are embedded in slides with small pores (for more information on second-generation DNA sequencing, see Table 2).

A wave of new sequencing technologies, named thirdgeneration DNA sequencing, have been developed with the promise of sequencing genomes, transcriptomes, and epigenomes faster and with lower costs. Some of these technologies are based on the so-called nanopores (Table 2). These pores are small holes that could be biological or solid, in which the DNA can pass and be detected in a controlled manner. ${ }^{47}$ These technologies rely on the detection of single molecules, and labeling of the sequencing substrate is sometimes required. It is possible that these new sequencers developed using nanotechnology could read long stretches of DNA in a greater or comparable way to the technologies that are currently available. A recent report has demonstrated that it is already possible to detect DNA methylation changes without the use of the reagent sodium bisulfite (which degrades the DNA and usually requires high amounts of starting material) ${ }^{48}$ This is possible in a single molecule real time sequencing reaction with nanodetectors. ${ }^{48}$ It is becoming clear that the new technologies under development will be of importance for research in epigenomics. This will have a positive impact on cancer research, facilitating the identification of new biomarkers and drug targets.

\section{Implications for cancer management}

The stratification of patients based on their tumor profile and/ or specific biomarkers is becoming the best way to subgroup individuals with the same tumor characteristics. This field is also known as personalized or individualized medicine, and its objective is to associate the best treatment for each specific patient or group of patients. Personalized medicine involves the systematic use of molecular information about each individual patient to select or optimize preventative and therapeutic care. These new approaches are changing the way in which pharmaceutical companies try to identify and test new cancer drugs. The idea of a blockbuster drug that could treat a broad spectrum of tumor types has become unlikely; cancer is a complex disease, and even a specific cancer type, such as breast cancer, has a variety of subclasses with completely different pathological and molecular features.

Epigenomics is a unique approach to cancer research since it can help in the identification of groups of patients with the same epigenetic changes and characteristics in their tumors. The epigenetic drugs used today are unspecific and have side effects such as the ones that occur in conventional chemotherapy. This can vary from patient to patient, depending on the dosage that is prescribed. Importantly, lower dose treatments can reduce the side effects. The identification of DNA methylation and histone modifications associated with cancer may have important clinical utility in the future. The development of new technologies to uncover these changes in a high-throughput fashion will have a major impact as discussed above and shown in Tables 2 and 3.

Some advancement in the field of epigenetics and epigenomics has already led to the identification of specific biomarkers to manage the disease (see Table 3 for more details). A variety of genes have been described as hypermethylated and/or hypomethylated in cancers, and this feature has shown some clinical significance in specific tumor types. ${ }^{49,50}$ Genes such as GSTP1, which is hypermethylated in a high percentage of prostate cancers, has been used as a biomarker for this disease in body fluids and biopsy specimens. ${ }^{51}$ In addition, groups of genes from the same pathway and/or network have shown the same epigenetic changes in tumors. Examples include genes implicated in cell adhesion, DNA repair, and apoptosis that can be downregulated by DNA methylation. Downregulation of genes associated with cell adhesion and migration can increase the risk of the tumor cells to metastasize to a secondary site in the body. ${ }^{52,53}$ For example, our group has already shown that the adhesion molecule ADAM23 is highly methylated in breast tumors, and this feature is correlated to metastases and a poor prognosis in breast tumors. ${ }^{54,55}$ A classic example of a DNA repair gene downregulated by DNA methylation is the $M G M T$ gene, which is silenced by epigenetic mechanisms in brain tumors. ${ }^{56}$ Tumors that do not express the gene $M G M T$ are more sensitive to radiotherapy and chemotherapy with temozolomide, and this molecular feature has been used in clinical decisions and disease management for glioblastomas. ${ }^{56,57}$ Changes in the profile of histone modifications have also been used to evaluate and manage the risk of prostate cancer recurrence in patients. ${ }^{58}$

Another group of genes in which epigenetic changes can be monitored to manage cancer risk and progression is the 
Table 3 Some examples of epigenetic and epigenomic changes in single genes or group of genes and their potential impact in cancer management

\begin{tabular}{|c|c|c|c|}
\hline Gene(s) & Epigenetic/epigenomic changes & Impact for cancer management & References \\
\hline GSTPI & $\begin{array}{l}\text { Hypermethylated in } 80 \%-90 \% \text { of } \\
\text { prostate cancers and unmethylated } \\
\text { in benign hyperplasic tissue. }\end{array}$ & $\begin{array}{l}\text { Detection of hypermethylated GSTPI could } \\
\text { help to distinguish normal prostate cells } \\
\text { from cancer cells. It could also be used as a } \\
\text { biomarker in body fluids and biopsy specimens. }\end{array}$ & 51 \\
\hline PI6ink4A & $\begin{array}{l}\text { One of the most common tumor suppressors } \\
\text { inactivated by DNA methylation in tumors. } \\
\text { Hypermethylation has been linked to poor } \\
\text { outcome in different types of cancer. }\end{array}$ & $\begin{array}{l}\text { pl bink } 4 A \text { could be used as } \\
\text { prognostic marker in cancer. }\end{array}$ & 100 \\
\hline $\begin{array}{l}\text { Apoptosis and cell } \\
\text { cycle genes (ie, DAPK, } \\
\text { p73, and others) }\end{array}$ & $\begin{array}{l}\text { Hypermethylation has been linked to } \\
\text { poor outcome in different types of cancer. }\end{array}$ & $\begin{array}{l}\text { Genes associated to apoptosis that are } \\
\text { hypermethylated in cancers could be } \\
\text { used as prognostic markers. }\end{array}$ & $101-103$ \\
\hline $\begin{array}{l}\text { Adhesion molecules } \\
\text { (ie, cadherins, ADAM23, } \\
\text { ADAM33, and others) }\end{array}$ & $\begin{array}{l}\text { Hypermethylated in different types of } \\
\text { cancer and associated with cancer metastasis. }\end{array}$ & $\begin{array}{l}\text { Genes associated to cell adhesion } \\
\text { could be used as markers for } \\
\text { disease progression. }\end{array}$ & $52-55,104$ \\
\hline $\begin{array}{l}\text { DNA repair genes } \\
\text { (ie, } M G M T, h M L H I, \\
\text { BRCAI, and others) }\end{array}$ & $\begin{array}{l}\text { Hypermethylation of genes implicated } \\
\text { in DNA repair could help in identifying tumors } \\
\text { that are more susceptible to therapies such as } \\
\text { radiotherapy helping in personalized treatment. }\end{array}$ & $\begin{array}{l}\text { The use of individualized therapies } \\
\text { could aid in patient outcome. }\end{array}$ & $56,57,105$ \\
\hline Histones & $\begin{array}{l}\text { Differential histone modifications such } \\
\text { as acetylation and methylation are associated } \\
\text { to cancer recurrence and a worse prognosis. }\end{array}$ & $\begin{array}{l}\text { The identification of patients that are at } \\
\text { more risk of recurrence of the disease could } \\
\text { help in decisions related to treatment and } \\
\text { a better follow-up into the clinic. }\end{array}$ & 58 \\
\hline miRNAs & $\begin{array}{l}\text { DNA methylation and histone } \\
\text { modifications of miRNA genes has } \\
\text { been reported by different groups. }\end{array}$ & $\begin{array}{l}\text { miRNAs are noncoding genes that can regulate } \\
\text { several proteins in a cellular network and/or pathway. } \\
\text { Reexpression of miRNAs in tumors may have an } \\
\text { impact for the regulation of key genes in the cells. }\end{array}$ & $60,70,106$ \\
\hline
\end{tabular}

Abbreviations: ADAM23, a desintegrin and metalloprotease domain 23; ADAM33, a desintegrin and metalloprotease domain 33; BRCA I, breast cancer gene I; DAPK, Deathassociated protein kinase; GSTPI, glutathione S-transferase PI; hMLHI, human mutL homolog I; MGMT, O6-methylguanine-DNA methyltransferase; miRNAs, microRNAs.

microRNA (miR) gene family. ${ }^{59}$ Some studies have already shown that miRs can be regulated by epigenetic mechanisms (Table 3). Changes in DNA methylation have been reported in specific cancer types for different miRs. ${ }^{60}$ Additionally, miRs are associated with important embryonic gene pathways in cancer, and this connection between embryonic development and cancer should be carefully examined for drug development in the future. ${ }^{61}$ Since miRs regulate hundreds to thousands of protein-coding genes by incomplete basepairing, ${ }^{62-64}$ allowing them to affect networks and pathways of genes, it will be of importance to monitor miR expression changes mediated by epigenetics during cancer initiation and progression.

In the case of drug development and new therapies, it is likely that the future of epigenetic therapy will include the use of multiple drugs that individually have little effect in epigenetic silencing but that might be expected to have synergistic and/or additional effects when combined. For example, a recent study using histone deacetylase inhibitors and high-dose chemotherapy both in vitro and in vivo indicated that this combination might overcome chemoresistance, achieve durable remission, and improve survival of patients with Burkitt lymphoma. ${ }^{65}$ A major problem with the use of current epigenetic drugs is that they are nonspecific and can reactivate genes randomly. A concern is that they can cause a whole-genome hypomethylation, increase the number of chromosomal abnormalities, and affect the tumorigenic phenotype of cancer cells as previously described. ${ }^{66,67}$ However, evidence that DNA methylation inhibitors act only in dividing cells, leaving nondividing cells unaffected, has already been reported. ${ }^{68}$ In addition, it seems that these drugs activate genes that have become abnormally silenced in cancer. ${ }^{69,70}$

The question we face today in the epigenomics field applied to cancer research is 'How to manage cancer with the new technologies and tools that are becoming available?' The new technologies under development will facilitate the identification of better epigenetic markers and may aid in the development of more specific therapies. These drugs will be focused in a group of genes and not the entire epigenome (see Table 1 for epigenetic drugs). The other question is 'What will be the impact of epigenomics in the clinics?' In other words, how could we translate the discoveries from basic science to the patient's bedside? In this regard, the FDA has already approved a few epigenetic 
Table 4 Examples of companies offering predictive epigenetic-based tests for cancer diagnosis and monitoring

\begin{tabular}{|c|c|c|c|}
\hline Company & Epigenetic test(s) & Impact for clinical decisions & Website \\
\hline $\begin{array}{l}\text { Oncomethylome } \\
\text { sciences }\end{array}$ & $\begin{array}{l}\text { MGMT methylation } \\
\text { analysis }\end{array}$ & $\begin{array}{l}\text { This test indicates if patients with unmethylated (functioning) } \\
\text { MGMT will benefit from the addition of } \\
\text { temozolomide to the standard treatment of radiation therapy. } \\
\text { Patients with methylated (silenced) MGMT } \\
\text { have longer progression-free and overall survivals with the } \\
\text { combination of radiation therapy and temozolomide. This company } \\
\text { also tests other genes for different tumor types in body fluids. }\end{array}$ & www.oncomethylome.com \\
\hline Epigenomics AG & $\begin{array}{l}\text { OncoSign and Epi } \\
\text { proColon }\end{array}$ & $\begin{array}{l}\text { Biomarker candidates are used to identify drug response } \\
\text { in cancer patients based in the DNA methylation analyses } \\
\text { of a set of genes. Other epigenetic tests are also offered } \\
\text { for colon cancer management facilitating clinical decisions. }\end{array}$ & www.epigenomics.com \\
\hline Sequenom & Cancer EpiPanels & $\begin{array}{l}\text { The Cancer EpiPanel contains targets of more than } 400 \text { cancer- } \\
\text { related genes. It includes prevalidated assays covering over 12,000 CpG } \\
\text { sites in promoter regions of genes known to be involved in neoplastic } \\
\text { transformation. The Cancer EpiPanel can be used to produce } \\
\text { quantitative DNA methylation profiles helping in tumor classification. }\end{array}$ & www.sequenom.com \\
\hline Exact sciences & $\begin{array}{l}\text { Stool-based DNA } \\
\text { methylation analyses }\end{array}$ & $\begin{array}{l}\text { The company offers noninvasive, molecular screening technologies } \\
\text { for the early detection of colorectal cancer using a combination } \\
\text { of DNA methylation markers. Stool-based DNA technology } \\
\text { is used for disease management. }\end{array}$ & www.exactsciences.com \\
\hline
\end{tabular}

drugs for different tumor types, and some of these are very promising (Table 1 and Figure 1). Molecular biomarkers, such as genes or groups of genes with changes in epigenetic modifications in tumors, have also been used to guide clinical decisions. Examples are epigenetic changes in GSTP1 in prostate cancer, p16ink $4 A$ in different types of cancer, and MGMT in brain tumors (see Table 3). There are companies (ie, Oncomethylome Sciences, Epigenomics AG, Sequenom, and others) already offering a test with a panel of epigenetic markers covering different genomic regions for cancers (see Table 4 for more details). More recently, the company Exact Sciences released a combined test for four methylation markers for early detection of colon cancer with a $100 \%$ sensitivity. The advantages of using epigenetic markers for early detection of cancer and disease monitoring is that the test can be done in a small tumor sample or even in body fluids such as stool, blood, spinal fluid, and urine. Depending on the combination of markers obtained after the tests, clinicians are able to predict the appearance of the disease and also group cancer patients based in tumor aggressiveness and other clinical features, facilitating clinical decisions. Clearly, the impact of epigenomics in cancer management is expected to increase with the advent and development of new technologies.

\section{Conclusions and future directions}

In conclusion, the burgeoning fields of genomics and epigenomics comprise essential facets of modern cancer research. The FDA has already approved some epigenetic drugs, and others are in clinical trials and under development, demonstrating that this field already affects the way we manage cancer. In addition, single genes and groups of genes from the same pathway have been identified as differentially methylated in cancers, and some have been used as molecular biomarkers in order to identify patients with a better or a worse prognosis. Histone modification changes have also been used as markers to monitor cancer patients. Clearly, epigenetic changes in tumors will affect the decisions that are made in the clinics for the patients, especially treatment regimens and disease progression monitoring. Future directions include the discovery of new biomarkers and the development of more efficient drugs against different tumor types with the evolving technologies and the emergence of a new generation of DNA sequencers. Based on the information discussed here, growing evidence indicates that new epigenomic tools will increasingly affect the way we monitor and manage cancer in the future.

\section{Acknowledgments}

The author acknowledges Dr Christopher A Hamm, Carl Radosevich, and Kelly Arndt for critically reading this manuscript. The author also thanks the Children's Memorial Research Center, The Falk Brain Tumor Foundation, The Maeve McNicholas Memorial Foundation, and the Avon Foundation (Grant \# 01-2009-037) for their financial support.

\section{Disclosure}

The author reports no conflicts of interest in this work. 


\section{Financial disclosure}

The author is the founder of the web-based company Genomic Enterprise and works as a consultant (www.genomicenter prise.com). Genomic Enterprise has the purpose of ensuring the integration of genetic, epigenetic, and genomic information to interested customers. Genomic Enterprise's objectives include the development of business-to-business (B2B), business-to-consumer (B2C), and consumer-to-business (C2B) services in the scientific field.

\section{References}

1. Venter JC, Adams MD, Myers EW, et al. The sequence of the human genome. Science. 2001;291(5507):1304-1351.

2. Lander ES, Linton LM, Birren B, et al. Initial sequencing and analyses of the human genome. Nature. 2001;409(6822):860-921.

3. Druker BJ, Talpaz M, Resta DJ, et al. Efficacy and safety of a specific inhibitor of the BCR-ABL tyrosine kinase in chronic myeloid leukemia. N Engl J Med. 2001;344(14):1031-1037.

4. Lossos IS, Czerwinski DK, Alizadeh AA, et al. Prediction of survival in diffuse large-B-cell lymphoma based on the expression of six genes. N Engl J Med. 2004;350(18):1828-1837.

5. Levy S, Sutton G, Ng PC, et al. The diploid genome sequence of an individual human. PLoS Biol. 2007;5(10):e254.

6. Wang J, Wang W, Li R, et al. The diploid genome sequence of an Asian individual. Nature. 2008;456(7218):60-65.

7. International HapMap Consortium. A haplotype map of the human genome. Nature. 2005;437(7063):1299-1320.

8. ENCODE Project Consortium. Identification and analysis of functional elements in $1 \%$ of the human genome by the ENCODE pilot project. Nature. 2007;447(7146):799-816.

9. López-Maury L, Marguerat S, Bähler J. Tuning gene expression to changing environments: from rapid responses to evolutionary adaptation. Nat Rev Genet. 2008;(8):583-593.

10. Callinan PA, Feinberg AP. The emerging science of epigenomics. Hum Mol Genet. 2006;15 Spec No 1:R95-R101.

11. Esteller M. Epigenetics in cancer. $N$ Engl J Med. 2008;358(11): 1148-1159.

12. Wilson VL, Jones PA, Momparler RL. Inhibition of DNA methylation in L1210 leukemic cells by 5-aza-2'-deoxycytidine as a possible mechanism of chemotherapeutic action. Cancer Res. 1983;43(8): 3493-3496.

13. Jones PA. Altering gene expression with 5-azacytidine. Cell. 1985; 40(3):485-486.

14. Jones PA, Taylor SM. Cellular differentiation, cytidine analogs and DNA methylation. Cell. 1980;20(1):85-93.

15. Pinto A, Zagonel V. 5-Aza-2'-deoxycytidine (Decitabine) and 5-azacytidine in the treatment of acute myeloid leukemias and myelodysplastic syndromes: past, present and future trends. Leukemia. 1993;7 Suppl 1: 51-60.

16. Karon M, Sieger L, Leimbrock S, et al. 5-Azacytidine: a new active agent for the treatment of acute leukemia. Blood. 1973;42(3):359-365.

17. Slamon DJ, Godolphin W, Jones LA. Studies of the HER-2/neu proto-oncogene in human breast and ovarian cancer. Science. 1989; 244(4905):707-712.

18. Paik S, Kim C, Wolmark N. HER2 status and benefit from adjuvant trastuzumab in breast cancer. $N$ Engl J Med. 2008;358(13): 1409-1411.

19. Ley TJ, Mardis ER, Ding L, et al. DNA sequencing of a cytogenetically normal acute myeloid leukaemia genome. Nature. 2008;456(7218): 66-72.

20. Stephens PJ, McBride DJ, Lin ML, et al. Complex landscapes of somatic rearrangement in human breast cancer genomes. Nature. 2009;462(7276):1005-1010.
21. Lee W, Jiang Z, Liu J, et al. The mutation spectrum revealed by paired genome sequences from a lung cancer patient. Nature. 2010; 465(7297):473-477.

22. Pleasance ED, Stephens PJ, O’Meara S, et al. A small-cell lung cancer genome with complex signatures of tobacco exposure. Nature. 2010; 463(7278):184-190.

23. Pleasance ED, Cheetham RK, Stephens PJ, et al. A comprehensive catalogue of somatic mutations from a human cancer genome. Nature. 2010;463(7278):191-196.

24. Beroukhim R, Mermel CH, Porter D, et al. The landscape of somatic copy-number alteration across human cancers. Nature. 2010; 463(7283):899-905.

25. Dalgliesh GL, Furge K, Greenman C, et al. Systematic sequencing of renal carcinoma reveals inactivation of histone modifying genes. Nature. 2010;463(7279):360-363.

26. Butler D. Human genome at ten: science after the sequence. Nature. 2010;465(7301):1000-1001.

27. Kaye J. The regulation of direct-to-consumer genetic tests. Hum Mol Genet. 2008;17(R2):R180-R183.

28. Esteller M. Epigenetic gene silencing in cancer: the DNA hypermethylome. Hum Mol Genet. 2007;16 Spec No 1:R50-R59.

29. Feinberg AP, Vogelstein B. Hypomethylation distinguishes genes of some human cancers from their normal counterparts. Nature. 1983; 301(5895):89-92.

30. Costa FF, Paixão VA, Cavalher FP, et al. SATR-1 hypomethylation is a common and early event in breast cancer. Cancer Genet Cytogenet. 2006;165(2):135-143.

31. Jones PA, Baylin SB. The fundamental role of epigenetic events in cancer. Nat Rev Genet. 2002;3(6):415-428.

32. Esteller M. Cancer epigenomics: DNA methylomes and histonemodification maps. Nat Rev Genet. 2007;8(4):286-298.

33. Turker MS. Gene silencing in mammalian cells and the spread of DNA methylation. Oncogene. 2002;21(35):5388-5393.

34. Jones PA, Baylin SB. The epigenomics of cancer. Cell. 2007;128(4): 683-692.

35. Bestor TH. The DNA methyltransferases of mammals. Hum Mol Genet 2000;9(16):2395-2402.

36. Robertson KD. DNA methylation, methyltransferases, and cancer Oncogene. 2001;20(24):3139-3155.

37. Eads CA, Danenberg KD, Kawakami K, et al. CpG island hypermethylation in human colorectal tumors is not associated with DNA methyltransferase overexpression. Cancer Res. 1999;59(10):2302-2306.

38. Fenaux P, Mufti GJ, Hellstrom-Lindberg E, et al. Efficacy of azacitidine compared with that of conventional care regimens in the treatment of higher-risk myelodysplastic syndromes: a randomised, open-label, phase III study. Lancet Oncol. 2009;10(3):223-232.

39. Bernstein BE, Mikkelsen TS, Xie X, et al. A bivalent chromatin structure marks key developmental genes in embryonic stem cells. Cell. 2006;125(2):315-326.

40. Kustatscher G, Ladurner AG. Modular paths to 'decoding' and 'wiping' histone lysine methylation. Curr Opin Chem Biol. 2007;11(6): 628-635.

41. Strahl BD, Allis CD. The language of covalent histone modifications. Nature. 2000;403(6765):41-45.

42. Sekeres MA, List AF, Cuthbertson D, et al. Phase I combination trial of lenalidomide and azacitidine in patients with higher-risk myelodysplastic syndromes. J Clin Oncol. 2010;28(13):2253-2258.

43. Lara E, Mai A, Calvanese V, et al. Salermide, a Sirtuin inhibitor with a strong cancer-specific proapoptotic effect. Oncogene. 2009; 28(6):781-791.

44. Brown CG. The DNA sequencing renaissance and its implications for epigenomics. Epigenomics. 2009;1(1):5-8.

45. Wang RY, Gehrke CW, Ehrlich M. Comparison of bisulfite modification of 5-methyldeoxycytidine and deoxycytidine residues. Nucleic Acids Res. 1980;8(20):4777-4790.

46. Kaneda A, Takai D, Kaminishi M, et al. Methylation-sensitive representational difference analysis and its application to cancer research. Ann N Y Acad Sci. 2003;983:131-141. 
47. Rhee M, Burns MA. Nanopore sequencing technology: research trends and applications. Trends Biotechnol. 2006;24(12):580-586.

48. Flusberg BA, Webster DR, Lee JH, et al. Direct detection of DNA methylation during single-molecule, real-time sequencing. Nat Methods. 2010;7(6):461-465.

49. Ehrlich M. Cancer-linked DNA hypomethylation and its relationship to hypermethylation. Curr Top Microbiol Immunol. 2006;310: 251-274.

50. Esteller M. Relevance of DNA methylation in the management of cancer. Lancet Oncol. 2003;4(6):351-358.

51. Woodson K, O'Reilly KJ, Hanson JC, et al. The usefulness of the detection of GSTP1 methylation in urine as a biomarker in the diagnosis of prostate cancer. J Urol. 2008;179(2):508-511.

52. Yu J, Cheng YY, Tao Q, Cheung KF, et al. Methylation of protocadherin 10 , a novel tumor suppressor, is associated with poor prognosis in patients with gastric cancer. Gastroenterology. 2009;136(2):640-651.

53. Kim DS, Kim MJ, Lee JY, et al. Aberrant methylation of E-cadherin and $\mathrm{H}$-cadherin genes in nonsmall cell lung cancer and its relation to clinicopathologic features. Cancer. 2007;110(12):2785-2792.

54. Costa FF, Verbisck NV, Salim AC, et al. Epigenetic silencing of the adhesion molecule ADAM23 is highly frequent in breast tumors. Oncogene. 2004;23(7):1481-1488.

55. Verbisck NV, Costa ET, Costa FF, et al. ADAM23 negatively modulates $\alpha v \beta 3$ integrin activation during metastasis. Cancer Res. 2009;69: $5546-5552$.

56. Esteller M, Garcia-Foncillas J, Andion E, et al. Inactivation of the DNArepair gene MGMT and the clinical response of gliomas to alkylating agents. N Engl J Med. 2000;343(19):1350-1354.

57. Hegi ME, Diserens AC, Gorlia T, et al. MGMT gene silencing and benefit from temozolomide in glioblastoma. N Engl J Med. 2005;352(10): 997-1003

58. Seligson DB, Horvath S, Shi T, et al. Global histone modification patterns predict risk of prostate cancer recurrence. Nature. 2005;435(7046): 1262-1266

59. Wurdinger T, Costa FF. Molecular therapy in the microRNA era. Pharmacogenomics J. 2007;7(5):297-304.

60. Lujambio A, Calin GA, Villanueva A, et al. A microRNA DNA methylation signature for human cancer metastasis. Proc Natl Acad Sci U SA. 2008;105(36):13556-13561.

61. Costa FF, Seftor EA, Bischof JM, et al. Epigenetically reprogramming metastatic tumor cells with an embryonic microenvironment. Epigenomics. 2009;1(2):387-398.

62. Bartel D. MicroRNAs: target recognition and regulatory functions. Cell. 2009;136(2):215-233.

63. Ambros V. The functions of animal microRNAs. Nature. 2004; 431(7006):350-355.

64. Passetti F, Ferreira CG, Costa FF. The impact of microRNAs and alternative splicing in pharmacogenomics. Pharmacogenomics J. 2009; 9(1):1-13.

65. Richter-Larrea JA, Robles EF, Fresquet V, et al. Reversion of epigenetically-mediated BIM silencing overcomes chemoresistance in Burkitt lymphoma. Blood. 2010. [Epub ahead of print].

66. Issa JP. DNA methylation as a therapeutic target in cancer. Clin Cancer Res. 2007;13(6):1634-1637.

67. Hamm CA, Xie H, Costa FF, et al. Global demethylation of rat chondrosarcoma cells after treatment with 5-aza-2-deoxycytidine results in increased tumorigenicity. PLoS One. 2009;4(12):e8340.

68. Liang G, Gonzales FA, Jones PA, et al. Analysis of gene induction in human fibroblasts and bladder cancer cells exposed to the methylation inhibitor 5-aza-2'-deoxycytidine. Cancer Res. 2002;62(4): 961-966.

69. de Smet C, de Backer O, Faraoni I, et al. The activation of human gene MAGE-1 in tumor cells is correlated with genome-wide demethylation. Proc Natl Acad Sci U SA. 1996;93(14):7149-7153.

70. Saito Y, Jones PA. Epigenetic activation of tumor suppressor microRNAs in human cancer cells. Cell Cycle. 2006;5(19):2220-2222.
71. Gimsing P, Hansen M, Knudsen LM, et al. A phase I clinical trial of the histone deacetylase inhibitor belinostat in patients with advanced hematological neoplasia. Eur J Haematol. 2008;81(3):170-176.

72. Tan J, Cang S, Ma Y, et al. Novel histone deacetylase inhibitors in clinical trials as anti-cancer agents. J Hematol Oncol. 2010;4:3-5.

73. Plimack ER, Kantarjian HM, Issa JP. Decitabine and its role in the treatment of hematopoietic malignancies. Leuk Lymphoma. 2007; 48(8):1472-1481.

74. Appleton K, Mackay HJ, Judson I, et al. Phase I and pharmacodynamic trial of the DNA methyltransferase inhibitor decitabine and carboplatin in solid tumors. J Clin Oncol. 2007;25(29):4603-4609.

75. Fiskus W, Wang Y, Sreekumar A, et al. Combined epigenetic therapy with the histone methyltransferase EZH2 inhibitor 3-deazaneplanocin A and the histone deacetylase inhibitor panobinostat against human AML cells. Blood. 2009;114(13):2733-2743.

76. Kakihana M, Ohira T, Chan D, et al. Induction of E-cadherin in lung cancer and interaction with growth suppression by histone deacetylase inhibition. J Thorac Oncol. 2009;4(12):1455-1465.

77. Gupta M, Ansell SM, Novak AJ, et al. Inhibition of histone deacetylase overcomes rapamycin-mediated resistance in diffuse large B-cell lymphoma by inhibiting Akt signaling through mTORC2. Blood. 2009;114(14):2926-2935

78. Chen S, Ye J, Kijima I, Evans D. The HDAC inhibitor LBH589 (panobinostat) is an inhibitory modulator of aromatase gene expression. Proc Natl Acad Sci U S A. 2010;107(24):11032-11037.

79. Kauh J, Fan S, Xia M, et al. c-FLIP degradation mediates sensitization of pancreatic cancer cells to TRAIL-induced apoptosis by the histone deacetylase inhibitor LBH589. PLoS One. 2010;5(4):e10376.

80. Brueckner B, Garcia Boy R, Siedlecki P, et al. Epigenetic reactivation of tumor suppressor genes by a novel small-molecule inhibitor of human DNA methyltransferases. Cancer Res. 2005;65(14):6305-6311.

81. Brueckner B, Rius M, Markelova MR, et al. Delivery of 5-azacytidine to human cancer cells by elaidic acid esterification increases therapeutic drug efficacy. Mol Cancer Ther. 2010;9(5):1256-1264.

82. Chuang JC, Warner SL, Vollmer D, et al. S110, a 5-aza-2'deoxycytidine-containing dinucleotide, is an effective DNA methylation inhibitor in vivo and can reduce tumor growth. Mol Cancer Ther. 2010;9(5):1443-1450.

83. Grant C, Rahman F, Piekarz R, et al. Romidepsin: a new therapy for cutaneous T-cell lymphoma and a potential therapy for solid tumors. Expert Rev Anticancer Ther. 2010;10(7):997-1008.

84. Duenas-Gonzalez A, Candelaria M, Perez-Plascencia C, et al. Valproic acid as epigenetic cancer drug: preclinical, clinical and transcriptional effects on solid tumors. Cancer Treat Rev. 2008;34(3):206-222.

85. Siegel D, Hussein M, Belani C, et al. Vorinostat in solid and hematologic malignancies. J Hematol Oncol. 2009;2:31.

86. Hrzenjak A, Kremser ML, Strohmeier B, et al. SAHA induces caspaseindependent, autophagic cell death of endometrial stromal sarcoma cells by influencing the mTOR pathway. J Pathol. 2008;216(4):495-504.

87. Alcaín FJ, Villalba JM. Sirtuin inhibitors. Expert Opin Ther Pat. 2009; 19(3):283-294

88. Herman JG, Graff JR, Myöhänen S, et al. Methylation-specific PCR: a novel PCR assay for methylation status of $\mathrm{CpG}$ islands. Proc Natl Acad Sci U S A. 1996;93(18):9821-9826.

89. Fraga MF, Esteller M. DNA methylation: a profile of methods and applications. Biotechniques. 2002;33(3):632-649.

90. Wu J, Smith LT, Plass C, Huang TH. ChIP-chip comes of age for genomewide functional analysis. Cancer Res. 2006;66(14):6899-6902.

91. Park PJ. ChIP-seq: advantages and challenges of a maturing technology. Nat Rev Genet. 2009;10(10):669-680.

92. Wang Y, Hayakawa J, Long F, et al. 'Promoter array' studies identify cohorts of genes directly regulated by methylation, copy number change, or transcription factor binding in human cancer cells. Ann NY Acad Sci. 2005; 1058:162-185.

93. van Steensel B, Henikoff S. Epigenomic profiling using microarrays. Biotechniques. 2003;35(2):346-350, 352-354, 356-357. 
94. Mardis ER. The impact of next generation sequencing technology on genetics. Trends Genet. 2008;(3)133-141.

95. Kircher M, Kelso J. High-throughput DNA sequencing - concepts and limitations. Bioessays. 2010;32(6):524-536.

96. Branton D, Deamer DW, Marziali A, et al. The potential and challenges of nanopore sequencing. Nat Biotechnol. 2008;26(10): $1146-1153$

97. Eid J, Fehr A, Gray J, et al. Real-time DNA sequencing from single polymerase molecules. Science. 2009;323(5910):133-138.

98. Drmanac R, Sparks AB, Callow MJ, et al. Human genome sequencing using unchained base reads on self-assembling DNA nanoarrays. Science. 2010;327(5961):78-81.

99. Ryan D, Rahimi M, Lund J, et al. Toward nanoscale genome sequencing. Trends Biotechnol. 2007;25(9):385-389.

100. Wettergren Y, Odin E, Nilsson S, et al. p16INK4a gene promoter hypermethylation in mucosa as a prognostic factor for patients with colorectal cancer. Mol Med. 2008;14(7-8):412-421.
101. Leung RC, Liu SS, Chan KY, et al. Promoter methylation of death-associated protein kinase and its role in irradiation response in cervical cancer. Oncol Rep. 2008;19(5):1339-1345.

102. Liu M, Taketani T, Li R, et al. Loss of p 73 gene expression in lymphoid leukemia cell lines is associated with hypermethylation. Leuk Res. 2001;25(6):441-447.

103. Gazin C, Wajapeyee N, Gobeil S, et al. An elaborate pathway required for Ras-mediated epigenetic silencing. Nature. 2007;449(7165): 1073-1077.

104. Seniski GG, Camargo AA, Ierardi DF, et al. ADAM33 gene silencing by promoter hypermethylation as a molecular marker in breast invasive lobular carcinoma. BMC Cancer. 2009;9:80.

105. Herman JG, Umar A, Polyak K, et al. Incidence and functional consequences of hMLH1 promoter hypermethylation in colorectal carcinoma. Proc Natl Acad Sci U S A. 1998;95(12):6870-6875.

106. Zhang H, Li Y, Lai M. The microRNA network and tumor metastasis. Oncogene. 2010;29(7):937-948.
Cancer Management and Research

\section{Publish your work in this journal}

Cancer Management and Research is an international, peer-reviewed open access journal focusing on cancer research and the optimal use of preventative and integrated treatment interventions to achieve improved outcomes, enhanced survival and quality of life for the cancer patient The journal welcomes original research, clinical \& epidemiological

\section{Dovepress}

studies, reviews \& evaluations, guidelines, expert opinion \& commentary, case reports \& extended reports. The manuscript management system is completely online and includes a very quick and fair peerreview system, which is all easy to use. Visit http://www.dovepress.com/ testimonials.php to read real quotes from published authors. 